\title{
Anticoagulant Activity of Mangrove (Avicennia alba) Leaves Extract in Vitro
}

\author{
Riza Rusyiana ${ }^{1}$, Ima Arum Lestarini², Candra Dwipayana Hamdin³, Handa Muliasari1 \\ ${ }^{1}$ Department of Pharmacy, Faculty of Medicine, Universitas Mataram \\ ${ }^{2}$ Clinical Pathology Division, Faculty of Medicine, Universitas Mataram \\ Jl. Majapahit No.62 Mataram, Nusa Tenggara Barat, Indonesia \\ ${ }^{3}$ Molecular and Biomedical Sciences, Department of Life Sciences, National Central University, Zhongli District, \\ Taoyuan City 32001, Taiwan \\ Email: handamuliasari@unram.ac.id
}

\begin{abstract}
Anti-coagulants are substances used to prevent the formation of thromboembolism, one of the causes of cardiovascular disease. Since cardiovascular is a disease as the leading cause of death in the world, exploration of novel and more effective anticoagulant is very needed. Mangroves contain flavonoid and sulphated polysaccharide compounds that potential as anti-coagulants. This study aimed to determine the anti-coagulant activity of ethanol extract and fractions of mangrove leaves (Avicennia alba) in human blood cells in vitro. A. alba leaves were collected at Teluk Ekas, East Lombok, Indonesia. The leaves were macerated with 96\% ethanol (3x24h) and then evaporated. The extract was then fractionated to obtain the $n$-hexane, chloroform, and residual fractions. Anti-coagulant activity of ethanol extract and the three fractions were tested in vitro to five human blood samples by the method of LeeWhite and Eustrek, compared to heparin as a positive control. Phytochemical screening of the ethanol extract indicated that $A$. alba leaves extract contains alkaloids, tannin, saponin, flavonoids, sulphated polysaccharide, and terpenoid. The results of Lee-White method were the ethanol extract (1 mg. $\left.\mathrm{mL}^{-1}\right)$, and three fractions $\left(0.5 \mathrm{mg} . \mathrm{mL}^{-1}\right)$ have anti-coagulant activity. Statistical analysis showed that the anti-coagulant activity of the ethanol extract was significantly different $(P<0.05)$ compared to the normal group and fractions and were not significantly different $(P>0.05)$ compared to heparin. Ethanol extract and the three fractions of $A$. alba leaves have anti-coagulant activity in vitro. The anti-coagulant activity of ethanol extract ( $\left.1 \mathrm{mg} \cdot \mathrm{mL}^{-1}\right)$ was comparable to heparin (25 IU) and was better than the three extract fractions $\left(0.5 \mathrm{mg} \cdot \mathrm{mL}^{-1}\right)$. Further research is needed to test the anticoagulant activities of isolated sulphated polysaccharides and flavonoid that can be developed as anticoagulant agents.
\end{abstract}

Keywords: Avicennia alba, leaves, anti-coagulant, Lee White, Eustrek

\section{Introduction}

Cardiovascular is a disease as the leading cause of death in the world. In 2008, the death rate because of cardiovascular disease was 17.3 million and this number predicts to increase significantly in 2030 to 23.3 million. Cardiovascular disease in Indonesia is also known to be the biggest cause of death as much as $37 \%$ of the total deaths caused by various diseases (WHO, 2014).

Thromboembolism is one of the causes of cardiovascular disease in the form of blocked arteries caused by blood clots. Some of the causes of thromboembolism are trauma, smoking, surgery, and drugs that contain estrogen. Drugs used for the prevention and treatment of thromboembolism are anti-coagulant, anti-thrombocyte, thrombolytic, and hemostatic groups (Michael and Zalika, 2017).

Anti-coagulants are substances used to prevent the formation of thromboembolism (Tangkery et al., 2013). Anti-coagulants work by inhibiting the function of several blood clotting factors such as serine zymogen protease, fibrinogen, thiol-dependent transglutaminase, regulatory proteins and other proteins (Sanjeey et al., 2014). The coagulation factor is a protein in the plasma that functions in the coagulation process. The coagulation mechanism progresses gradually until one of the coagulation factors is changed to be active and ends with fibrin formation (Murray et al., 2003). In pandemic of Corona virus disease 2019 (Covid-19), anticoagulant treatment gives a greatly benefit to decreased mortality in severe Covid-19 patients with coagulopathy (Tang et al., 2020).

Anti-coagulant compounds commonly used to prevent or reduce the occurrence of blood clots in vitro are EDTA, heparin, sodium citrate 3.8\%, and a mixture of ammonium oxalate with potassium oxalate (Desmawati, 2013). Those anti-coagulants are obtained synthetically and cause side effects if used excessively. For example, long-term use of heparin causes bleeding of blood vessels in the brain and trombocytopenia (Gandasoebrata, 2013; Shobharani 
et al., 2014; Oliveira et al., 2016). In addition, the price of these materials is quite expensive so that the development of natural anti-coagulants from plant is very needed to minimize side effects at a more affordable price (Harter et al., 2014; Khouya et al., 2015).

Mangroves are plants that have the potency as anti-coagulants. Lombok Island is a producer of various types of mangroves in West Nusa Tenggara, such as Rhizophoraceae, Avicenniaceae, Myrsinaceae, Myrtaceae, Combretaceae and Meliaceae (Anwar and Martha, 2017). A. alba is the most abundant species of mangrove growth in Teluk Ekas, Jerowaru, East Lombok. The information of chemical constituent and anti-coagulant activities of this species are unknown yet.

Based on some research such as Handayani (2013) states that crude extracts of other mangrove species contain bioactive alkaloids, steroids/ triterpenoids, flavonoids, tannins and contain sulphated-polysaccharides (Kathiresan et al., 2006). Kathiresan et al. (2006) also mentioned that the genus Avicennia had the highest anti-coagulant activity with sulphated polysaccharides content of 3.16-3.36\%. This study investigates anti-coagulant activity of mangrove leaves ( $A$. alba) from Lombok.

\section{Materials and Methods}

\section{Plant material}

Mangrove (Avicennia alba) leaves were collected from Teluk Ekas, Jerowaru district, East Lombok, West Nusa Tenggara, Indonesia. The identification and authentication of the sample was conducted in Biology Laboratory, Faculty of Mathematics and Natural Sciences, Mataram University with identification number of 37/UN18.7/LB/2019.

\section{Preparation of extract and fractions}

A. alba leaves were air dried and powdered, and then extracted by using maceration method with $96 \%$ ethanol $(3 \times 24 \quad \mathrm{~h})$. The extract was then concentrated with rotary evaporator (Tangkery et al., 2013). Fractionation was carried out to the leaves extracted with three different polarity of solvents to obtain n-hexane, chloroform and residual fraction.

\section{Phytochemical screening}

Phytochemical screening of the extract was carried out to identify alkaloid, flavonoid, saponin, tannin, steroid/triterpenoid and sulphated polysaccharides (Handayani, 2013; Kathiresan et al., 2006).

\section{Anti-coagulant activity assay}

Blood samples were collected from five men as volunteers with no more than $70 \mathrm{~kg}$ body weight, healthy physical condition, the age among 21-27 years old, and did not have a history of prolonged bleeding. The volunteers filled in the closed questionnaire and informed consent to make sure that they do not have blood disorders. Blood samples were taken from the cubitus vein by using a $10 \mathrm{~mL}$ disposable syringe and a $22 \mathrm{G}$ sterile needle. The number of samples taken from each volunteer was 6 $\mathrm{mL}$. This research was previously approved by the ethics committee of the Faculty of Medicine, University of Mataram with approval letter number No.63/UN18.F7/ETIK/2018. The letter stated that in this study there were no procedures that could potentially violate ethics.

The anti-coagulant activity of ethanol extract and fractions of $A$. alba leaves was observed in vitro. The anti-coagulant activity test was carried out by 2 methods, namely the Lee-White method and the Eustrek (Blood smear) method. The first method, the modified Lee-White method (Gandasoebrata, 2013) was used to determine the blood clotting period which is observed visually such as liquid, thick, very thick and frozen. The working procedure of the modified Lee-White method was as follows: prepared 6 test tubes with a diameter of $8 \mathrm{~mm}$, which are clean and labeled number 1 through number 6 . The tubes are placed in a tube rack.

One $\mathrm{mL}$ of blood was put into each test tube and treated according to the six research treatments: (1) Normal blood (1 mL); (2) Positive Control: Blood (1 $\mathrm{mL})+$ heparin $25 \mathrm{IU}$; (3) Blood $(1 \mathrm{~mL})+$ ethanol extract (1 mg.mL-1); (4) Blood (1 mL) + N-hexane fraction (0.5 mg. $\left.\mathrm{mL}^{-1}\right)$; (5) Blood $(1 \mathrm{~mL})+$ chloroform fraction (0.5 mg. $\left.\mathrm{mL}^{-1}\right)$; and (6) Blood (1 mL) + residual fraction (0.5 mg. mL-1). Each tube was vortexed until homogeneous, and then the blood clotting time or period was observed with a stopwatch. After 5 mins, the tubes were taken from the rack and each was marked to see whether blood clots have occurred or not. If no freezing has occurred, the tube is put back on the test tube rack and every 30 seconds the same procedure was repeated.

The second method, Eustrek method was to analyze the microscopic visualization of the blood after treatments in Lee-White Method (Rahmawati, 2018). Two drops of blood were taken from each test tube after 20, 60 and 240 mins of treatments. The blood was then dipped on the slide, covered with a glass cover, and observed under a microscope with 400x objective magnification. 


\section{Result and Discussion}

\section{Characteristic of the extract}

The yield of ethanol extract of $A$. alba leaves obtained was $13.6 \% \mathrm{w} / \mathrm{w}$. Organoleptic test results of the ethanol extract of $A$. alba leaves were greenish brown in color and have a distinctive odor of mangrove extract. This is in accordance with the research of Handayani (2013) which states that the ethanol extract of the mangrove api-api leaves ( $A$. marina) was greenish brown and has a distinctive odor of mangrove extract.

\section{Phytochemical screening result}

The phytochemical screening results obtained in accordance with research of Rahmania et al. (2018) which states that $A$. alba leaves contains alkaloid compounds, steroid/ triterpenoid, tannin, saponin and flavonoid. See Table 1. In addition, according to Kathiresan et al. (2006), the genus Avicennia contains sulphated polysaccharide compounds.

Sulphated polysaccharides (SPs) are complex and heterogeneous macromolecules that previously reported to find at high concentrations in marine algae. Researchers have found and isolated various sulphated polysaccharides from brown algae, green algae, and red algae, which were reported to have anticoagulant properties (Rodrigues et al., 2011; Jin et al., 2013; Liang et al., 2014). The anticoagulant effect of this sulphated polysaccharide was mainly due to the potentiation of thrombin inhibition by heparin cofactor II but it had no effect on anti-Xa activity (Majdoub et al., 2009). The presence of sulphated polysaccharides in marine algae as well as in a salt resistant plant (halophyte) suggests a possible correlation between the presence of these compounds and salt tolerance (Aquino et al., 2011).
Based on Table 2, the yield percentage of $n$ hexane fraction, chloroform fraction and residual fraction obtained ranged from $25-30 \%$. The number of different yields in each fraction is influenced by differences in solvent based on the level of polarity (Tursiman et al., 2012).

\section{Anti-coagulant activity test using the Lee-White method}

The average results of observing blood clotting masses after administration of ethanol extract and the three fractions are shown in Table 3. The results of anti-coagulant activity tests using the Lee-White method showed that there were differences in the average blood clotting mass between negative control, positive control and all three fractions treatments. Negative control was illustrated on a scale of 5 , positive control and ethanol extract were illustrated on a scale of 1 and the three fractions were illustrated on a scale of 2 . According to the result, concluded that ethanol extract and all three fractions have anti-coagulant activity.

Data on the average scale of blood clotting masses were analyzed using the Kruskall Wallis test. The value obtained $P<0.05$ which indicated a significant difference between each group. The MannWhitney test was then performed to compare anticoagulant activities between each group. MannWhitney test results showed that between negative control (normal blood) and positive control (Heparin) had a value of $P<0.05$ which means that it was significantly different. Blood samples (negative control) from each donor had a blood coagulation time of 5-10 mins. These results were in accordance with the theory of Bitthel (1993) in Tangkery et al. (2013) which states that normal blood clots occur in a span of 3-18 mins. Meanwhile, blood samples

Table 1. Phytochemical screening result of ethanol extract of Avicennia alba leaves

\begin{tabular}{|c|c|c|}
\hline No & Chemical Compound & Result \\
\hline 1 & Alkaloids & + \\
\hline 2 & Steroids / Triterpenoids & + \\
\hline 3 & Tannin & + \\
\hline 4 & Saponin & + \\
\hline 5 & Flavonoids & + \\
\hline 6 & Sulphated Polysaccharides & + \\
\hline
\end{tabular}

Note: (+) positively contains compounds, (-) does not contain compounds

Table 2. Characteristic of the fractions of Avicennia alba leaves extract

\begin{tabular}{|c|c|c|c|c|}
\hline Fraction & Color & Odor & Texture & Yield Percentage \% w / w \\
\hline n-hexane & Blackish green & Typical mangrove extracts & Rough & 30 \\
\hline Chloroform & Blackish green & Typical mangrove extracts & Rough & 25 \\
\hline Residue & Brown & Typical mangrove extracts & Rough & 30 \\
\hline
\end{tabular}


added with heparin (positive control) did not experience blood clots for 240 mins.

Heparin can prevent blood clots and increase the process of fibrinolysis. The mechanism of heparin as an anti-coagulant is by binding to antithrombin III to form a larger complex, especially thrombin and factor Xa. Small doses of heparin with antithrombin III inactivate factor Xa which can prevent the change of prothrombin to thrombin so that no blood clotting process occurs (Aldallal, 2017).

Positive control did not have a significant difference $(P>0.05)$ with ethanol extract. This showed that the anti-coagulant activity of ethanol extract was comparable to heparin. While the three fractions did not have a significant difference $(P>0.05)$ between each group of fractions which meant that the three fractions had comparable anti-coagulant activity.
In the ethanol extract phytochemical testing, it was found that there were flavonoid compounds and sulphated polysaccharides which were potential as anti-coagulants. According to Guglielmone et al (2002) flavonoid compounds work by inhibiting fibrinogen which is the first factor in blood clotting; while sulphated polysaccharides work with antithrombin III which inhibits thrombin from converting fibrinogen to fibrin (Rahmawati, 2018). The anticoagulant effect of this sulphated polysaccharide was mainly due to the potentiation of thrombin inhibition by heparin cofactor II but it had no effect on anti-Xa activity (Majdoub et al., 2009).

Based on the results of macroscopic observations and statistical tests using the Lee-White method, ethanol extract ( $1 \mathrm{mg} \cdot \mathrm{mL}^{-1}$ ) has better anticoagulant activity than the three extract fractions $(0.5$ $\left.\mathrm{mg} \cdot \mathrm{mL}^{-1}\right)$. This was indicated that the blood liquid

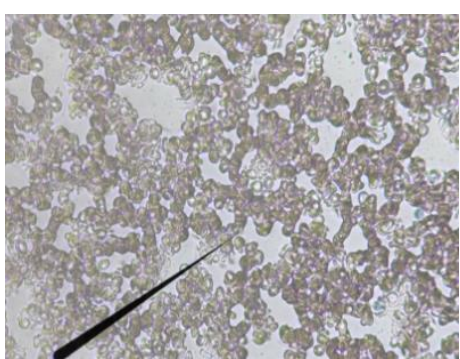

A-1

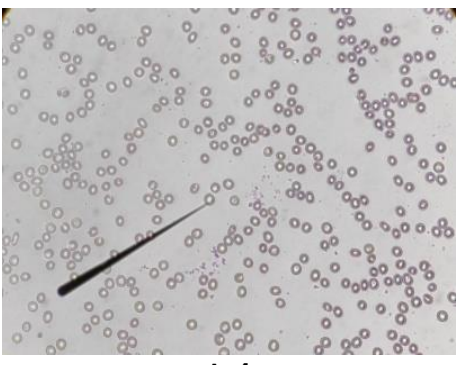

A-4

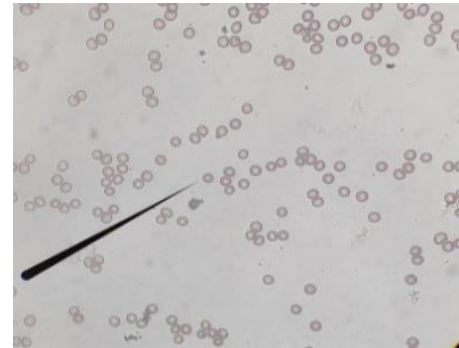

$\mathrm{A}-2$

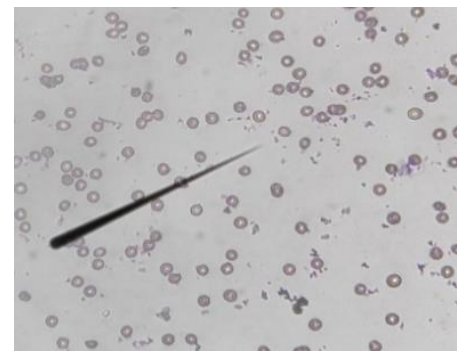

A-5

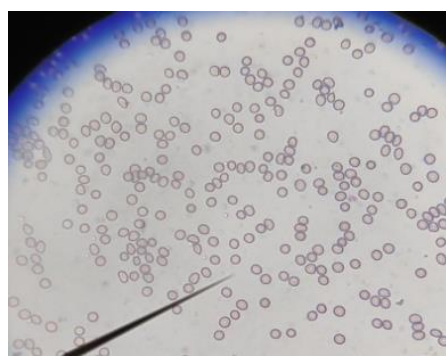

A-3

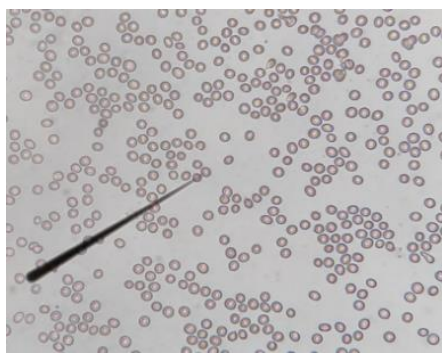

A-6

Figure 1. Microscopic Results of Blood Swabs after 20 mins treatments. A-1: Normal; A-2: Heparin 25 IU.mL-1; A-3: ethanol extract of $1 \mathrm{mg} \cdot \mathrm{mL}^{-1} ; \mathrm{A}-4$ : $\mathrm{n}$-hexane fraction of $0.5 \mathrm{mg} \cdot \mathrm{mL}^{-1} ; \mathrm{A}-5$ : Chloroform fraction of $0.5 \mathrm{mg} \cdot \mathrm{mL}^{-1} ; \mathrm{A}-6$ : Residue fraction of $0.5 \mathrm{mg} \cdot \mathrm{mL}^{-1}$. Samples were observed under light microscope with $400 x$ objective magnification.

Table 3. Observation results of mean blood clotting mass of 5 donors

\begin{tabular}{|c|c|c|c|c|}
\hline \multirow{2}{*}{$\begin{array}{l}\text { Glass } \\
\text { bject }\end{array}$} & \multirow{2}{*}{ Treatment } & \multicolumn{3}{|c|}{ Scale for Measurement of Blood Clotting Mass } \\
\hline & & $20^{\prime}$ & 60 & 240 \\
\hline 1 & Negative control: Normal blood $(1 \mathrm{~mL})$ a & 5 & 5 & 5 \\
\hline 2 & Positive control: Blood $(1 \mathrm{~mL})+$ heparin $\left(25 \mathrm{IU} \cdot \mathrm{mL}^{-1}\right) \mathrm{b}$ & 1 & 1 & 1 \\
\hline 3 & Blood $(1 \mathrm{~mL})+$ ethanol extract $\left(1 \mathrm{mg} \cdot \mathrm{mL}^{-1}\right)^{\mathrm{b}}$ & 1 & 1 & 1 \\
\hline 4 & Blood $(1 \mathrm{~mL})+\mathrm{N}$-hexane fraction $\left(0.5 \mathrm{mg} \cdot \mathrm{mL}^{-1}\right) \mathrm{c}$ & 2 & 2 & 2 \\
\hline 5 & Blood $(1 \mathrm{~mL})+$ chloroform fraction $\left(0.5 \mathrm{mg} \cdot \mathrm{mL}^{-1}\right) \mathrm{c}$ & 2 & 2 & 2 \\
\hline 6 & Blood $(1 \mathrm{~mL})+$ residual fraction $\left(0.5 \mathrm{mg} \cdot \mathrm{mL}^{-1}\right) \mathrm{c}$ & 2 & 2 & 2 \\
\hline
\end{tabular}

Note * 1= Liquid; $2=$ liquid with a little lump; $3=$ Thick; 4= Very thick; $5=$ Frozen; * Different letters represent statistically significantly different test results 


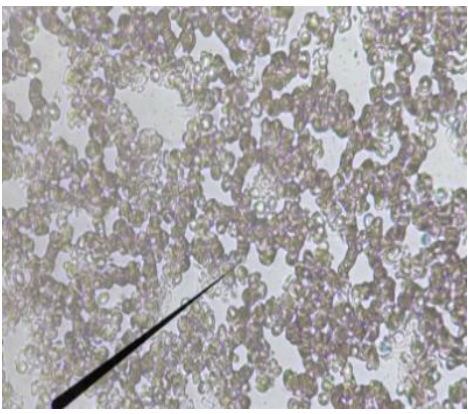

B-1

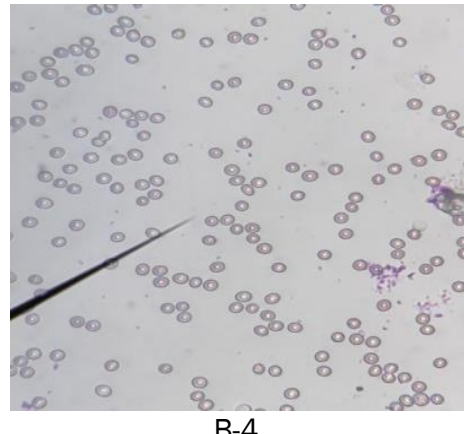

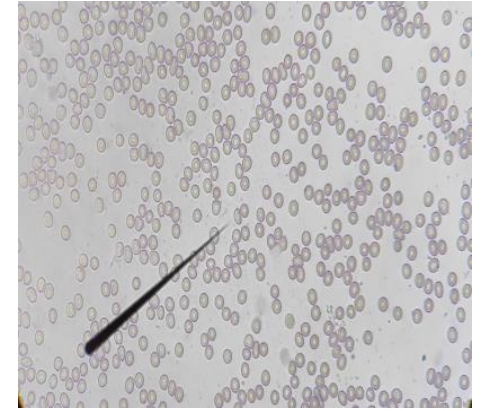

B-2

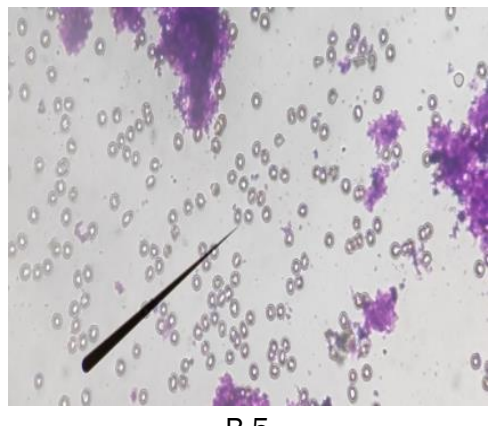

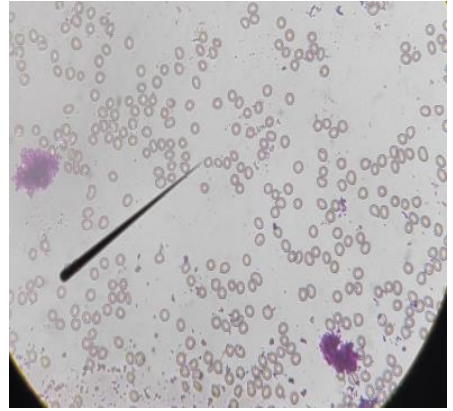

B-3

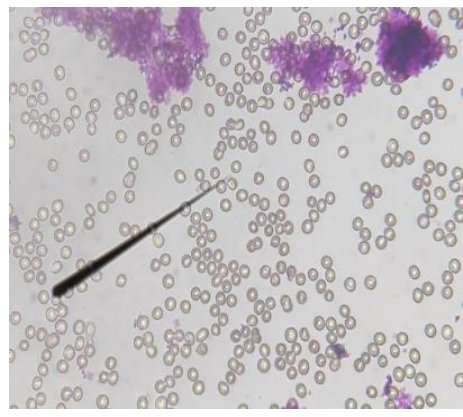

B-6

Figure 2. Microscopic Results of Blood Swabs after 60 mins treatments. B-1: Normal; B-2: Heparin 25 IU.mL-1; B-3: ethanol extract of $1 \mathrm{mg} \cdot \mathrm{mL}^{-1}$; B-4: $\mathrm{n}$-hexane fraction of $0.5 \mathrm{mg} \cdot \mathrm{mL}^{-1}$; B-5: Chloroform fraction of $0.5 \mathrm{mg} \cdot \mathrm{mL}^{-1}$; B-6: Residue fraction of $0.5 \mathrm{mg} \cdot \mathrm{mL}^{-1}$. Samples were observed under light microscope with $400 x$ objective magnification.

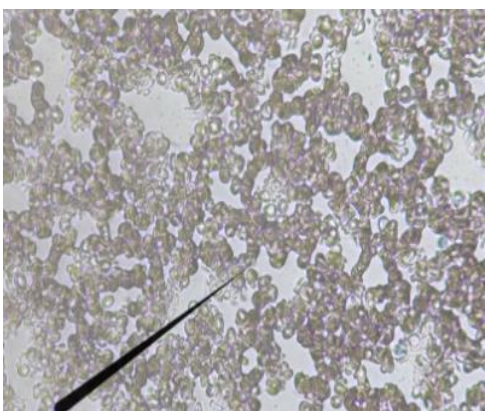

C-1

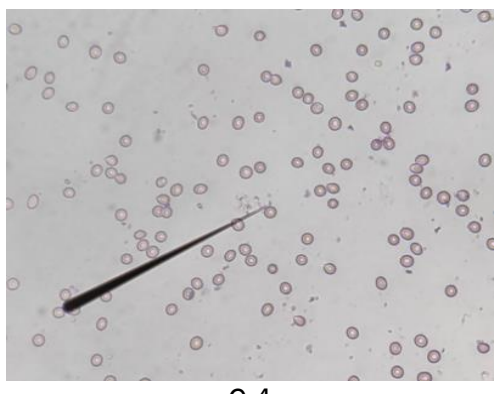

C-4

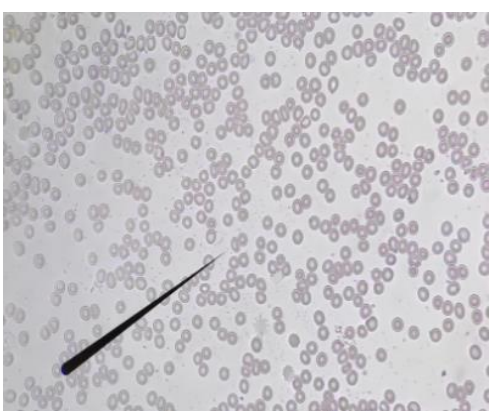

C-2

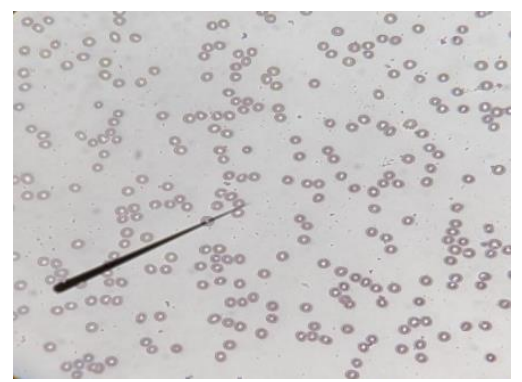

C-5

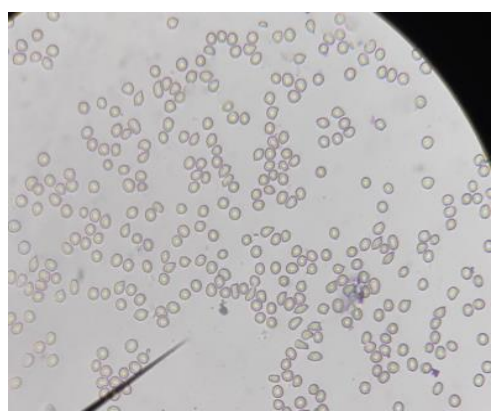

C-3

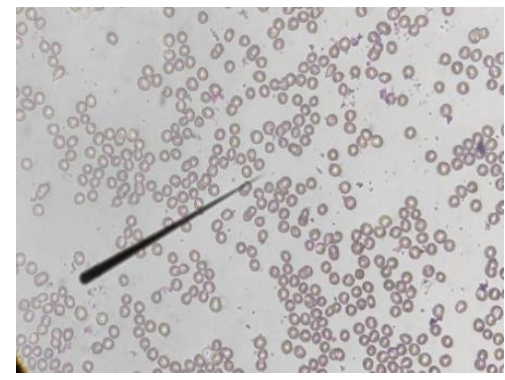

C-6

Figure 3. Microscopic Results of Blood Swabs after 240 mins treatments. C-1: Normal; C-2: Heparin 25 IU.mL-1; C-3: ethanol extract of $1 \mathrm{mg} \cdot \mathrm{mL}^{-1}$; C-4: $\mathrm{n}$-hexane fraction of $0.5 \mathrm{mg} \cdot \mathrm{mL}^{-1}$; C-5: Chloroform fraction of $0.5 \mathrm{mg} \cdot \mathrm{mL}^{-1}$; C-6: Residue fraction of $0.5 \mathrm{mg} \cdot \mathrm{mL}^{-1}$. Samples were observed under light microscope with $400 x$ objective magnification.

added by ethanol extract which remains liquid while the three extract fractions form small lumps. The difference was thought due to the synergistic effect of the chemical compounds in ethanol extract compared to the fraction so that the ethanol extract anti-coagulant activity was better. It also means that 
the active compounds of sulphated polysaccharides and flavonoid are optimally extracted by using ethanol. Thus, ethanol extract is the best choice to develop as anti-coagulant agent in comparison with n-hexane, chloroform and water as solvent.

\section{Anti-coagulant activity test with Eustrek method (blood smear)}

Testing with this method was carried out to look at the state of blood cells microscopically taken from one of the donors. Based on Figure 1- Figure 3, it can be seen that the blood mass in ethanol extract and the three fractions were liquid, characterized by the presence of scattered and non-attached blood cells. This condition occurs because cells that did not freeze were round erythrocytes (Rahmawati, 2018). Normal blood (negative control) in Figure A-1, B-1, and $\mathrm{C}-1$ showed that blood cells were not separated from each other because they have undergone normal blood clotting mechanisms. These blood cells usually appear more dense because blood cells attach to one another and red blood cells (erythrocytes) no longer have a shape (Tangkery et al., 2013).

In anti-coagulant activity testing by using the Lee-White and Eustrek method, it was shown that ethanol extract and all three fractions had anticoagulant activity. This was evidenced by the consistency of blood that remains liquid (macroscopic) and the form of separate blood cells in blood smears (microscopy). Therefore, ethanol extract of $A$. alba leaves is very potential to develop as a novel and more effective natural anticoagulant.

Some previous research reported that mangrove has anticoagulant activity. Aqueous extracts of Acanthus ilicifolius roots and Lumnitzera racemose leaves showed anticoagulant, but these two mangrove species had only slightly prolonged the coagulation times compared with the control sample, suggesting that extracts inhibited the common pathways but isn't too effective compared to Heparin (Paul and Ramasubbu, 2017). Genus Avicennia (A. marina) exhibited the highest anticoagulant property among another genus teste due to the high level of sulphated polysaccharide. Avicennia spp. grow usually luxuriant along the muddy coastal areas and are easier to cultivate. Thus, Avicennia could provide abundant source material for extracting anticoagulant (Kathiresan et al., 2006).

\section{Conclusion}

Ethanol extract and the three fractions of $A$. alba leave have anti-coagulant activity in vitro. The anti-coagulant activity of ethanol extract ( $1 \mathrm{mg} \cdot \mathrm{mL}^{-1}$ ) was comparable to heparin (25 IU) and was better than the three extract fractions (0.5 mg. $\left.\mathrm{mL}^{-1}\right)$. Further research is needed to test the anticoagulant activities of isolated sulphated polysaccharides and flavonoid to be developed as anticoagulant agents.

\section{References}

Aldallal, S.M. 2017. Heparin in HIT: Effectiveness as an Anticoagulant. International Journal of Pharmaceutical Sciences and Research., 8(8): 3261-64, doi: 10.13040/IJPSR.0975-8232.8 (8).3261-64.

Anwar, H. \& Martha, I.G., 2017. Composition of Mangrove Species in Gerupuk Bay, Central Lombok. Sangkareang Mataram J., 3(2): 25-30.

Aquino, R.S., Grativol, C. \& Mourão, P.A.S. 2011. Rising from the sea: Correlations between sulfated polysaccharides and salinity in plants. Plos One, 6(4): e18862. doi: 10.1371/ journal.pone.0018862.

Desmawati, 2013. Determination of the Speed of Expending Mother's Milk after Sectio Caesarae. Jakarta Veterans National Development University. J. Kemas, 7(8): 360-364. doi: 10.211 09/kesmas.v7i8.22.

Gandasoebrata, R. 2013. Clinical Laboratory Guides. 15th Edition. Jakarta: Dian Rakyat. pp.56-58.

Goglielmone, H., Susana, N.M., Alicia, M.A \& Jose, L.C. 2002. Anticoagulant Effect and Action Mechanism of Sulphated Flavonoids from Flaveria Bidentis. Thrombosis Research 105:183-188. doi: 10.1016/S0049-3848(01) 00419-4.

Handayani, S., 2013. Flavonoid Content of Bark and Leaf Leaves (Avicennia marina (Forks.) Vierh.) As Antioxidant Active Compounds Thesis. Bogor: Bogor Agricultural University.

Harter, K., Levine, M. \& Henderson, S.O. 2015. Anticoagulation drug therapy: A review. West. J. Emerg. Med., 16(1):11-17. doi: 10.5811/westj em.2014.12.22933.

Jin, W., Zhang, Q., Wang, J. \& Zhang, W. 2013. A comparative study of the anticoagulant activities of eleven fucoidans. Carbohydrate Polymers, 91(1):1-6. doi: 10.1016/j.carbpol.2012.07.067

Kathiresan, K., Vinoth, S.R. \& Muruganantham, A., 2006. Mangrove Extracts Prevent the Blood Coagulate. Indian J. Biotechnolog., 5: 252-254. 
Khouya, T., Ramchoun, M., Hmidani, A., Amrani, S., Harnafi, H., Benlyas, M., Zegzouti, Y.F. \& Alem, C. 2015. Anti-inflammatory, anti-coagulant and antioxidant effects of aqueous extracts from Moroccan thyme varieties. Asian Pac. J. Trop. Biomed., 5 (8):636-44. doi: 10.1016/j.apjtb. 2015.05.011.

Liang, W.N., Mao, X., Peng, X.H. \& Tang, S.Q. 2014. Effects of sulfate group in red seaweed polysaccharides on anticoagulant activity and cytotoxicity, Carbohydrate Polymers, 101: 776785. doi: 10.1016/j.carbpol.2013.10.010.

Majdoub, H., Mansour, M.B., Chaubet, F., Roudesli, M.S. \& Maaroufi, R.M. 2009. Anticoagulant activity of a sulfated polysaccharide from the green alga Arthrospira platensis. Biochimica et Biophysica Acta - General Subjects, 1790(10): 1377-1381. doi:10.1016/j.bbagen.2009.07.013.

Murray, R.K., Graner, D.K., Mayes, P.A. \& Radwel, V.W. 2003. Harper's. Illustrated Biochemistry. 26th Edition. New York: McGraw-Hill Companies. pp.270-272.

Oliveira, R.C.R., Almeida, R.R. \& Goncalves, T.A. 2016. A Review of Plant Sulfated Polysaccharides and their Relations with Anticoagulant Activities. J. Dev. Drugs, 5(3):3-5. doi: 10.4172/23296631.1000166.

Paul, T. \& Ramasubbu, S. 2017. The antioxidant, anticancer and anticoagulant activities of Acanthus ilicifolius L. roots and Lumnitzera racemosa Willd. leaves, from southeast coast of India. J. App. Pharma. Sci., 7(3): 81-87. doi: 10.7324/JAPS.2017.70313.

Rahmania, N., Herpandi \& Rozirwan., 2018. Phytochemical Test of Mangrove Avicennia alba, Rhizophora apiculata and Sonneratia alba from Musi River Estuary, South Sumatra. Biovalentia: Biolog. Res. J., 4(2): 3-4. doi: 10.24233/BIOV. 4.2.2018.116.
Rahmawati, Muammar, F., Rais, R. \& I., Utami. 2018. Potential of Anti-coagulant Garlic Extract (Allium sativum) Using Lee-White Method and Blood Destruction. Majalah Farmeseutik., 14(1):42-48 doi: 10.22146/farmaseutik.v14I1 .41927.

Rodrigues, J.A.G., Vanderlei, E.S.O., Bessa, É.F., Magalhães, F.A., Paula, R.C.M., Lima, V., Benevides, N.M.B. 2011. Anticoagulant activity of a sulfated polysaccharide isolated from the green seaweed Caulerpa cupressoides. Brazilian Arc. Biol. Technolog., 54(4): 691-700. doi: 10.1590 /s1516-89132011000400007.

Sanjeey, P., Richa, S. \& Anshu, P., 2014. Overview of The Coagulation System. Indian J. Anaesthesia, 58(5): 515-523. doi: 10.4103/0019-5049.14 4643.

Shobharani, P., Nanishankar, V.H., Halami, P.M. \& Sachindra, N.M. 2014 Antioxidant and anticoagulant activity of polyphenol and polysaccharides from fermented Sargassum sp, Int. J. Biol. Macromol., 65: 542-548. doi: 10.10 16/j.ijbiomac.2014.02.005.

Tang, N., Bai, H., Chen, X., Gong, J., Li, D. \& Sun, Z. 2020. Anticoagulant treatment is associated with decreased mortality in severe coronavirus disease 2019 patients with coagulopathy. J. Thromb. Haemost., 18(5): 1094-1099. doi: 10.1111/jth.14817.

Tangkery, R.A.B., Paransa, D.S. \& Rumengan, A., 2013. Anti-coagulant Activity Test for Mangrove Extract Aegiceras corniculatum. J. Coast. Trop. Seas, 1(1): 7-9.

Tursiman, Praise, A. \& Risa, N., 2012. Total Phenol Acetate Faction from Kandis Acid Fruit (Garcinia diocia Blume). J. Equatorial Chem., 1(1): 45-48.

World Health Organization (WHO)., 2014. Global Status Report on Non-communicable Diseases. Geneva: WHO Press. 